\title{
Global prevalence of chronic obstructive pulmonary disease: system- atic review and meta-analysis
}

\author{
Mehdi Varmaghani ${ }^{1,2}$, Mina Dehghani ${ }^{2,3}$, Elham Heidari ${ }^{2}$, Farshad Sharifi ${ }^{4}$, Sahar Saeedi Moghaddam ${ }^{2,5}$ and Farshad Farzadfar $^{2,6}$
}

${ }^{1}$ Social Determinants of Health Research Center, Mashhad University of Medical Sciences, Mashhad, Islamic Republic of Iran. ${ }^{2}$ Non-Communicable Disease Research Center, Endocrinology and Metabolism Population Sciences Institute, Tehran University of Medical Sciences, Tehran, Islamic Republic of Iran. ${ }^{3}$ Department of Pharmacoeconomics and Pharmaceutical Administration, Faculty of Pharmacy, Tehran University of Medical Sciences, Tehran, Islamic Republic of Iran. ${ }^{4}$ Elderly Health Research Center, Endocrinology and Metabolism Population Sciences Institute, Tehran University of Medical Sciences, Tehran, Islamic Republic of Iran. ${ }^{5}$ Department of Biostatistics, Faculty of Paramedical Sciences, Shahid Beheshti University of Medical Sciences, Tehran, Islamic Republic of Iran. ${ }^{6}$ Endocrinology and Metabolism Research Center, Endocrinology and Metabolism Clinical Sciences Institute, Tehran University of Medical Sciences, Tehran, Islamic Republic of Iran. (Correspondence to: Farshad Farzadfar: f-farzadfar@tums.ac.ir).

\begin{abstract}
Background: Chronic obstructive pulmonary disease (COPD) is a leading cause of morbidity and mortality worldwide. Aims: To synthesize data on the worldwide prevalence and severity of COPD by geographical region, age groups, and smoking status in a systematic review.

Methods: A systematic search was performed following Meta-analysis of Observational Studies in Epidemiology (MOOSE) guidelines. International databases including PubMed, Scopus and Web of Science were searched for population-based studies published between January 2004 and May 2015 that reported the prevalence of COPD anywhere in the world. The prevalence of COPD was calculated based on World Health Organization (WHO) regions and sex and severity stages using metaprop. Meta-regression and subgroup analysis were applied to determine the sources of heterogeneity.

Results: Sixty papers were screened with a combined subject sample size of 127598 . The prevalence of post-bronchodilator COPD was $12.16 \%$ (10.91-13.40\%). The pooled prevalence of COPD was $15.70 \%(13.80-18.59 \%)$ in men and $9.93 \%(8.73-$ $11.13 \%)$ in women. Among all WHO regions, the highest prevalence was recorded in the Region of the Americas (14.53\%), and the lowest was recorded in the South-East Asia Region/Western Pacific Region (8.80\%). Meta-regression model variables were: sample size, WHO region, study quality score, level of gathering data, publication year, and sampling methods that justified $29.82 \%$ of heterogeneity detected among COPD prevalence rates worldwide.
\end{abstract}

Conclusions: Global prevalence of COPD among men is about 5\% higher than among women. The most prevalent stage of COPD is stage 1.

Keywords: chronic obstructive pulmonary disease, spirometry, GOLD criteria, systematic review, meta-analysis.

Citation: Varmaghani M; Dehghani M; Heidari E; Sharifi F; Moghaddam SS; Farzadfar F. Global prevalence of chronic obstructive pulmonary disease: systematic review and meta-analysis. East Mediterr Health J. 2019;25(1):47-57. https://doi.org/10.26719/emhj.18.014

Received: 07/03/17; accepted: 14/09/17

Copyright @ World Health Organization (WHO) 2019. Some rights reserved. This work is available under the CC BY-NC-SA 3.0 IGO license (https:// creativecommons.org/licenses/by-nc-sa/3.o/igo).

\section{Introduction}

Chronic obstructive pulmonary disease (COPD) is a leading cause of morbidity and mortality globally. According to the Global Burden of Disease (GBD) study, COPD rose from the eighth to the fifth leading cause of global burden of disease from 1990 to 2013. In 2013, COPD was the fourth leading cause of death globally, and it is predicted that COPD will become the third leading cause by 2020 (1).

Emphysema and bronchitis can cause loss of daily function in many ways (2), and impose a massive and growing burden, both in direct and indirect costs to society. For example, in 2010, the cost of COPD in the United States of America was estimated at US\$ 50 billion, which included US\$ 30 billion of direct healthcare expenditure and US\$20 billion of indirect costs (3). In Italy, as a European example, the total cost of a COPD patient has been calculated as $€ 2706.70$, of which $€ 2460.40$ is direct costs and $€ 246.30$ is indirect costs (4).
A recently published systematic review and metaanalysis that included studies based on different definitions of COPD without distinguishing between them reported the global prevalence of COPD (5), so the pooling of data based on these 2 different definitions was not reasonable. Thus, we undertook a new metaanalysis of COPD prevalence, according to data based on clinically distinct definitions separately. We analysed the worldwide COPD prevalence according to the standard definition of Global Initiative for Chronic Obstructive Lung Disease (GOLD). Additionally, we estimated the COPD prevalence by geographic regions, clinical severity stages, age groups, and smoking status.

\section{Methods}

\section{Study design}

The study was designed as a systematic review and meta-analysis of the published literature on COPD. It was performed according to Meta-analysis of Observational 
Studies in Epidemiology (MOOSE) guidelines (7).

\section{Definitions}

There are several different definitions of COPD in the literature. In this study, we used the GOLD definition (8): the presence of a post-bronchodilator forced expiratory volume in 1 second/forced vital capacity (FEV1/FVC) < 0.70. The stages of COPD were defined as follows: mild COPD or stage I: $\mathrm{FEV} 1 / \mathrm{FVC}<70 \%$ and $\mathrm{FEV} 1 \geq 80 \%$ predicted; moderate COPD or stage II: $\mathrm{FEV} / \mathrm{FVC}<70 \%$ and $50 \%$ $\leq \mathrm{FEV} 1<80 \%$ predicted; severe COPD or stage III: $\mathrm{FEV} 1 /$ $\mathrm{FVC}<70 \%$ and $30 \% \leq \mathrm{FEV} 1<50 \%$ predicted; and very severe COPD or stage IV: $\mathrm{FEV} 1 / \mathrm{FVC}<70 \%$ and $\mathrm{FEV} 1<30 \%$ predicted.

\section{Search strategy}

We searched PubMed, Scopus and Web of Science (ISI) databases for population-based studies published between January 2004 and May 2015 that reported the prevalence of COPD worldwide. The inclusion and exclusion criteria were applied to full-text articles. PubMed was searched using medical subject headings (MeSH) terms, and Scopus was searched using Emtree terms. We also considered all the references and related published systematic reviews in various regions. Figure 1 depicts the search flow diagram, and the search strategy is provided in Online Resource 1.

\section{Inclusion and exclusion criteria}

The study included the total sampling population (i.e., survey respondents or general population, population-based cohort studies and population-based case-control studies). From all sampling articles specific groups were excluded as well as studies published in languages other than English, studies using a definition of COPD other than the GOLD definition, and studies conducted before 2004. If the full-text of a study was unavailable, up to 3 requests were e-mailed to the corresponding authors. The reference lists of related systematic reviews were also checked for further studies that might be eligible for inclusion. Two independent reviewers examined the titles and the abstract, then the full texts of the studies to see if they met the inclusion criteria. In case of disagreement, the principal investigator made the final decision.

\section{Data extraction}

The data were extracted into a standardized Excel spreadsheet approved by the GBD investigators, including study variables such as name of first author, year of publication, study region, total sample size, response rate, age and sex of participants, number of subjects with COPD or point prevalence based on demographics and severity stages, and $95 \%$ confidence intervals of the point prevalence. All data were double-checked by another researcher to ensure it was accurate.

The included studies $(6,9-56)$ were from the following World Health Organization (WHO) regions: 2 from the African Region, 2 from the South-East Asia Region, 30 from the European Region, 4 from the Eastern
Mediterranean Region, 13 from the Western Pacific Region, and 10 from the Region of the Americas. Also, 1 study that was conducted at an international level was included. Because of the scarcity of data, the Eastern Mediterranean Region was merged into the African Region, and South-East Asia Region was merged into the Western Pacific Region. The characteristics of the studies included are described in Table 1.

\section{Study quality assessment}

The quality of the studies was scored according to the GBD quality assessment checklist. The total study quality score ranged from 1 to 24 and was based on summing up the level of gathering data (subdistrict $=1$, district $=$ 2 , provincial $=3, \geq 2$ provinces $=4, \geq 2$ subgroups $=5$, and national $=6$ ); sampling method (multilevel clustering random $=1,1$ level clustering random $=2$, random simple sampling $=3$, random stratified sampling $=4$, and census $=5)$; sample size code $(<1000=1,1000-5000=2$, $5000-10000=3,>10000=4$ ); study design (case control $=1$, cohort $=2$, cross-sectional $=3$ ); and response rate code $(<59 \%=0,60-74 \%=2,75-89 \%=4$, and $>90 \%=6)$.

\section{Statistical analysis}

The aggregated prevalence of COPD was calculated based on WHO region, sex, and severity stage using metaprop random effects analysis in Stata version 12. Forest plots illustrated both the pooled and individual data of the surveys. We used I2 for calculating the heterogeneity among the studies included. Meta-regression and subgroup analysis methods were used to determine the sources of heterogeneity. We carried out meta-regression based on quality assessment score, WHO regions, sample size, level of gathering data, publication year, and sampling methods. In addition, subgroup analysis was applied using regions, sex, and severity stages. In order to increase the data points, we estimated the post-bronchodilator COPD prevalence by crosswalking using a regression model from pre-bronchodilator data.

\section{Results}

\section{Characteristics of the studies included}

The primary search recognized 61588 published papers, including 22639 in PubMed, 15916 in Web of Science and 23033 in Scopus. From those, 15578 articles were eliminated after removal of duplicates. Thereafter, 45503 studies were excluded after reading the titles and abstracts. Finally, a total of 60 papers, with a combined subject sample size of 127598, met the inclusion criteria (Figure 1).

\section{Estimated prevalence of COPD}

The prevalence of post-bronchodilator COPD was calculated using a crosswalking method for 16 papers. The $\mathrm{R} 2$ of the regression model was 0.97. Using the random effects method, the prevalence of COPD in terms of post-bronchodilator COPD was $12.16 \%$ (10.91-13.40\%) (Table 2). By regions, COPD prevalence ranged from $8.80 \%$ in the combined South-East Asia and Western Pacific Regions to $14.53 \%$ in the Region of the Americas. The pooled 


\begin{tabular}{|c|c|c|c|c|c|}
\hline First author (ref) & Year of publication & Country & Age (yr) & WHO Region & Quality score \\
\hline De Marco (18) & 2004 & International & $20-40$ & 4 & 17 \\
\hline Fukuchi (22) & 2004 & Japan & $>40$ & 6 & 13 \\
\hline Johannessen (6) & 2005 & Norway & $26-82$ & 4 & 13 \\
\hline $\operatorname{Kim}(26)$ & 2005 & Korea & $>45$ & 6 & 11 \\
\hline Kotaniemi (28) & 2005 & Finland & $21-70$ & 4 & 11 \\
\hline Lindberg (55) & 2005 & Sweden & $23-72$ & 4 & 12 \\
\hline Menezes (54) & 2005 & America & $>40$ & 2 & 18 \\
\hline Sichletidis (41) & 2005 & Greece & $21-80$ & 4 & 17 \\
\hline Wilson (50) & 2005 & Australia & $>18$ & 6 & 11 \\
\hline $\operatorname{Kim}(27)$ & 2006 & Republic of Korea & $40-69$ & 6 & 13 \\
\hline Lindberg (29) & 2006 & Sweden & $46-77$ & 4 & 14 \\
\hline Shahab (40) & 2006 & United Kingdom & $>35$ & 4 & 14 \\
\hline Al-Hazmi (12) & 2007 & Canada & $20-44$ & 2 & 13 \\
\hline Buist (10) & 2007 & Australia & $>40$ & 6 & 16 \\
\hline Buist (10) & 2007 & Iceland & $>40$ & 4 & 18 \\
\hline Buist (10) & 2007 & Austria & $>40$ & 4 & 18 \\
\hline Buist (10) & 2007 & Canada & $>40$ & 2 & 16 \\
\hline Buist (10) & 2007 & China & $>40$ & 6 & 20 \\
\hline Buist (10) & 2007 & Germany & $>40$ & 4 & 18 \\
\hline Buist (10) & 2007 & Norway & $>40$ & 4 & 18 \\
\hline Buist (10) & 2007 & Philippines & $>40$ & 6 & 16 \\
\hline Buist (10) & 2007 & Poland & $>40$ & 4 & 20 \\
\hline Buist (10) & 2007 & South Africa & $>40$ & 1 & 20 \\
\hline Buist (10) & 2007 & Turkey & $>40$ & 4 & 20 \\
\hline Buist (10) & 2007 & United States of America & $>40$ & 2 & 16 \\
\hline Frank (21) & 2007 & United Kingdom & $>30$ & 4 & 5 \\
\hline Nizankowska-Mogilnicka (37) & 2007 & Poland & $>40$ & 4 & 14 \\
\hline Schirnhofer (39) & 2007 & Austria & $>40$ & 4 & 12 \\
\hline Shirtcliffe (42) & 2007 & New Zealand & $>25$ & 6 & 12 \\
\hline Zhong (51) & 2007 & China & $>40$ & 6 & 15 \\
\hline Caballero (15) & 2008 & Colombia & $>40$ & 2 & 14 \\
\hline Hansen (9) & 2008 & Denmark & $45-84$ & 4 & 20 \\
\hline Mahesh (30) & 2009 & India & $>40$ & 3 & 15 \\
\hline Methvin (34) & 2009 & United States of America & $>40$ & 2 & 8 \\
\hline Bridevaux (14) & 2010 & Switzerland & $>30$ & 4 & 11 \\
\hline Melville (33) & 2010 & United Kingdom & $45-69$ & 4 & 11 \\
\hline Minas (35) & 2010 & Greece & $>30$ & 4 & 10 \\
\hline Szanto (43) & 2010 & Sweden & $60-93$ & 4 & 9 \\
\hline Al Zaabi (11) & 2011 & United Arab Emirates & $40-80$ & 5 & 14 \\
\hline Fabricius (19) & 2011 & Denmark & $>35$ & 4 & 8 \\
\hline Hwang (23) & 2011 & Republic of Korea & $>40$ & 6 & 13 \\
\hline Mascarenhas (31) & 2011 & Portugal & $>40$ & 4 & 8 \\
\hline Petrescu (52) & 2011 & Romania & $45-74$ & 4 & 9 \\
\hline $\operatorname{Tan}(44)$ & 2011 & Canada & $>35$ & 2 & 13 \\
\hline Danielsson (17) & 2012 & Sweden & $>40$ & 4 & 8 \\
\hline Joo (24) & 2012 & Republic of Korea & $>40$ & 6 & 11 \\
\hline Vanfleteren (48) & 2012 & Netherlands & $>40$ & 4 & 8 \\
\hline Arslan (13) & 2013 & Turkey & $>40$ & 4 & 15 \\
\hline Daldoul (16) & 2013 & Tunisia & $>40$ & 1 & 11 \\
\hline Ford $(20)$ & 2013 & United States of America & $20-79$ & 2 & 19 \\
\hline Kainu (25) & 2013 & Finland & $20-79$ & 4 & 9 \\
\hline Toelle (46) & 2013 & Australia & $>40$ & 4 & 12 \\
\hline Chuchalin (56) & 2014 & Russian Federation & $20-88$ & 4 & 12 \\
\hline Lâm (45) & 2014 & Viet Nam & $23-72$ & 6 & 9 \\
\hline Wali (49) & 2014 & Saudi Arabia & $>40$ & 5 & 21 \\
\hline Matsumoto (32) & 2015 & Japan & $>40$ & 6 & 6 \\
\hline Miravitlles (36) & 2015 & Spain & $40-80$ & 4 & 15 \\
\hline Parasuramalu (38) & 2015 & India & $>35$ & 3 & 12 \\
\hline Sharifi (53) & 2015 & Islamic Republic of Iran & $>40$ & 5 & 11 \\
\hline Van Gemert (47) & 2015 & Uganda & $30-49$ & 1 & 18 \\
\hline
\end{tabular}

UK = United Kingdom of Great Britain and Northern Ireland; USA = United States of America. 


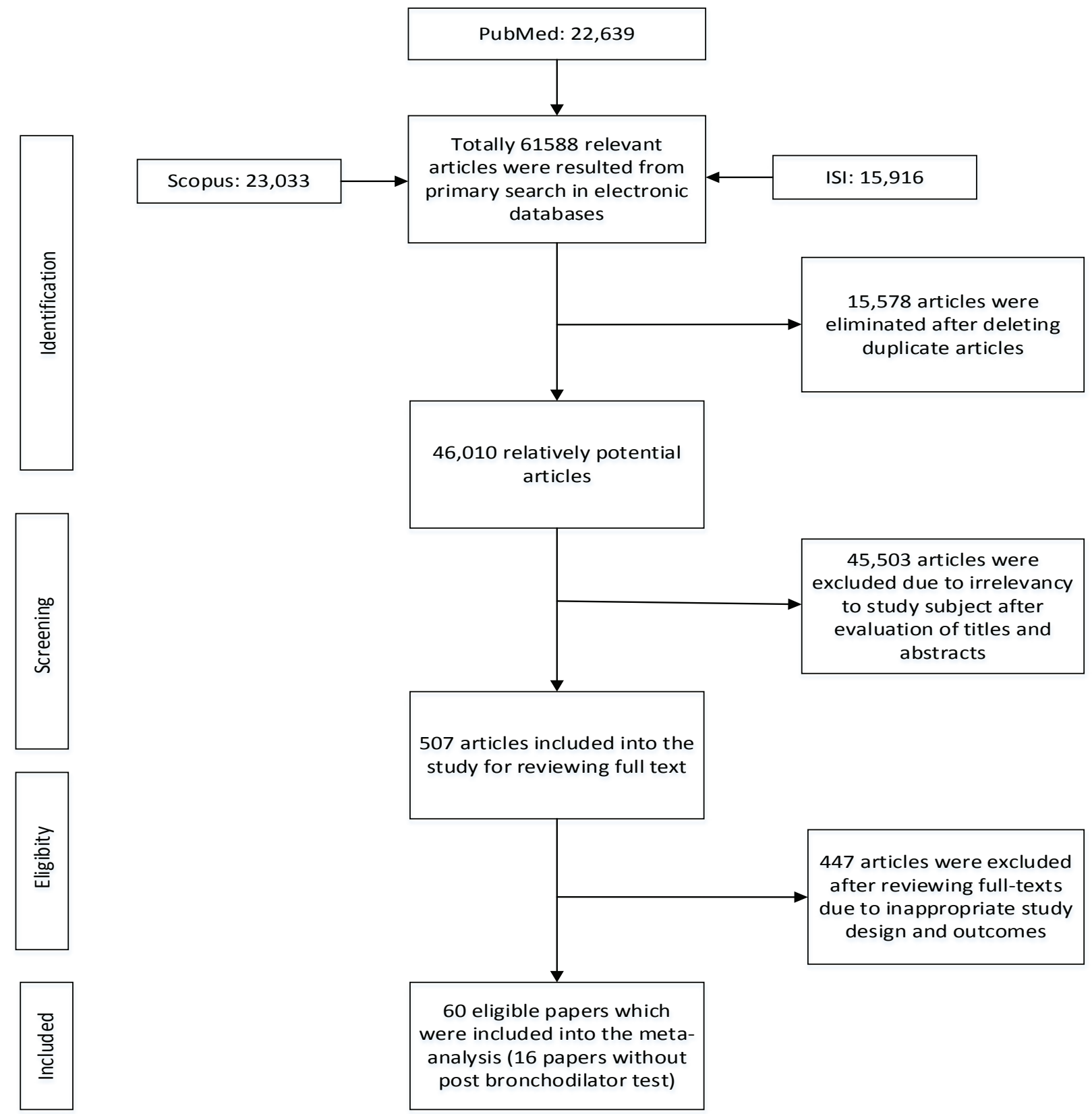

Figure 1 Process of search and analysis for selection of studies conducted on chronic obstructive pulmonary disease.

prevalence of COPD according to sex was $15.70 \%$ in men and $9.93 \%$ in women. The most common stage of COPD was stage I $(7.06 \%)$ and the least common were stages III and IV (1.61\%).

The COPD prevalence among different stages, both sexes, and WHO regions is shown in Online Resource 2. Furthermore, the COPD prevalence was calculated according to age groups and smoking status. The prevalence of COPD was increased from $5.28 \%$ in the $<50$ years group to $21.38 \%$ in the $\geq 60$ years group (Table 3 ). In terms of smoking status, the least prevalence was found with the never smoked group $(7.20 \%)$ and the highest prevalence was in the current smokers (18.36\%).

\section{Meta-regression}

Univariate and multivariate meta-regression analyses were conducted to detect sources of heterogeneity. Meta-regression model variables were: sample size, WHO Region, study quality score, level of gathering data, publication year, and sampling method (Table 4). In the univariate models, significant factors were WHO region, level of gathering data, and sample size. None of the factors could justify the total heterogeneity in the meta-analysis and the mentioned factors explained just $29.82 \%$ of the heterogeneity.

\section{Discussion}

We found that more than $12 \%$ of the general population of the world suffered from COPD. Among all the patients, $44.16 \%$ had mild COPD, $44.22 \%$ had moderate COPD, and the rest had severe COPD. Our results indicate a higher global prevalence of COPD than that in a previously pub- 


\begin{tabular}{|c|c|c|c|c|}
\hline Stage & WHO Region & Male (\%) & Female (\%) & Total (\%) \\
\hline \multirow[t]{5}{*}{ I } & SEA-WP & $6.15(3.83-8.47)$ & $2.31(1.43-3.18)$ & $4.40(2.88-5.93)$ \\
\hline & Americas & $9.39(6.08-12.71)$ & $6.37(3.82-8.93)$ & $8.53(7.18-9.89)$ \\
\hline & EM-Africa & $6.50(4.27-9.78)$ & $3.30(2.09-5.18)$ & $3.24(2.33-4.15)$ \\
\hline & European & $9.60(5.63-13.57)$ & $6.27(4.06-8.48)$ & $7.74(5.79-9.69)$ \\
\hline & Total & $8.63(6.75-10.52)$ & $4.68(3.65-5.72)$ & $7.06(5.90-8.21)$ \\
\hline \multirow[t]{5}{*}{ II } & SEA-WP & $6.32(3.35-9.29)$ & $3.26(1.84-4.69)$ & $4.95(2.92-6.99)$ \\
\hline & Americas & $7.07(5.13-9.0)$ & $7.03(3.80-10.27)$ & $5.59(4.39-6.79)$ \\
\hline & EM-Africa & $14.20(10.78-18.49)$ & $11.00(8.62-13.94)$ & $6.44(5.16-7.72)$ \\
\hline & European & $10.20(8.49-11.92)$ & $5.98(4.25-7.70)$ & $8.14(6.95-9.33)$ \\
\hline & Total & $8.61(6.68-10.54)$ & $5.48(4.25-6.71)$ & $6.58(5.41-7.74)$ \\
\hline \multirow[t]{5}{*}{ III/IV } & SEA-WP & $2.46(0.70-4.23)$ & $4.23(0.33-1.74)$ & $1.69(0.58-2.63)$ \\
\hline & Americas & $0.75(0-1.68)$ & $1.57(0.32-2.81)$ & $0.96(0.68-1.24)$ \\
\hline & EM-Africa & $8.00(5.49-11.53)$ & $5.70(4.03-8.01)$ & $0.08(0-0.29)$ \\
\hline & European & $2.16(1.38-2.94)$ & $1.15(0.81-1.50)$ & $1.89(1.40-2.37)$ \\
\hline & Total & $2.62(1.85-3.39)$ & $1.27(0.97-1.57)$ & $1.61(1.30-1.92)$ \\
\hline \multirow[t]{5}{*}{ All stages } & SEA-WP & $12.28(9.91-14.64)$ & $6.24(4.65-7.83)$ & $8.80(7.08-10.52)$ \\
\hline & America & $17.19(13.39-21.00)$ & $12.26(9.74-14.78)$ & $14.53(12.04-17.02)$ \\
\hline & EMR-Africa & $11.57(5.57-17.57)$ & $10.25(3.87-16.63)$ & $9.98(4.51-15.46)$ \\
\hline & European & $18.03(15.66-20.39)$ & $11.06(9.23-12.89)$ & $13.29(11.22-15.35)$ \\
\hline & Total & $15.70(13.80-17.59)$ & $9.93(8.73-11.13)$ & $12.16(10.91-13.40)$ \\
\hline
\end{tabular}

EM = Eastern Mediterranean; SEA = South-East Asia; WHO = World Health Organization; WP = Western Pacific.

lished meta-analysis (5). The higher prevalence calculated in our study may have been because we considered more recent studies than the previous meta-analysis did. In addition, the previous meta-analysis did not distinguish between different COPD definitions (5). Moreover, it did not consider the severity of COPD, which is a critical factor in specific mortality and burden of COPD. The present study was designed to resolve these shortcomings. Another finding of our study was that the prevalence of COPD increased at a steady rate with ageing of population. These findings are consistent with previous studies $(57,58)$. Also, we observed that the prevalence of COPD among individuals who had ever smoked was more than twice as high as that among those who had never smoked. This finding confirms that smoking is one of the most important risk factors for COPD (59).

It seems that the prevalence of COPD is increasing. A worldwide prevalence of $8.9 \%$ was reported in $2006(60)$, based on a meta-analysis of 37 papers, which was lower than the prevalence in the most recent analysis in 2015 (5). It is possible that the difference resulted from using different definitions of COPD. Furthermore, our results are consistent with the findings of some regional studies $(61,62)$, in which the prevalence of COPD was closer to our results than others (5).

The prevalence of COPD is usually more common among men than women $(63,64)$. Our meta-analysis also demonstrated a higher prevalence among men. This difference could be due to higher occupational risks (65) or higher rates of smoking among men (66). The highest prevalence of COPD was observed in the Region of the Americas and the lowest in the South-East Asia Region/Western Pacific Region. These results are consistent with the results of Adeloye et al. (5). Our pooled estimation of the prevalence for the regions is also close to the prevalence reported by regional studies $(61,62)$. This variability of the prevalence between the different regions is partially explained by the level of industrialization, the prevalence of smoking, the geographic situation, and the ethnicities of the populations (67-69). Martin et al. reported a higher rate of COPD among those of white

\begin{tabular}{|c|c|c|}
\hline \multicolumn{3}{|c|}{$\begin{array}{l}\text { Table } 3 \text { Prevalence of COPD according to age-groups and } \\
\text { smoking status }\end{array}$} \\
\hline & $\begin{array}{c}\text { Point } \\
\text { prevalence of } \\
\text { COPD (\%) }\end{array}$ & $\begin{array}{l}95 \% \text { confidence } \\
\text { interval } \\
(\%)\end{array}$ \\
\hline \multicolumn{3}{|l|}{ Age groups, yr } \\
\hline$<50$ & 5.28 & $4.08-6.49$ \\
\hline $50-59$ & 10.16 & $7.94-12.37$ \\
\hline$\geq 60$ & 21.38 & $18.42-25.40$ \\
\hline \multicolumn{3}{|l|}{ Smoking status } \\
\hline Current smokers & 18.36 & $15.38-21.34$ \\
\hline Ex-smokers & 16.33 & $14.49-18.17$ \\
\hline Never smokers & 7.20 & $6.26-8.13$ \\
\hline
\end{tabular}

COPD $=$ chronic obstructive pulmonary disease. 


\begin{tabular}{|c|c|c|c|c|c|c|c|c|}
\hline \multirow[t]{2}{*}{ Variable } & \multicolumn{4}{|c|}{ Univariate analysis } & \multicolumn{4}{|c|}{ Multivariate analysis } \\
\hline & Coefficient & SE & $\mathbf{P}^{*}$ & $\begin{array}{c}\text { Adjusted } \\
\text { R2 (\%) }\end{array}$ & Coefficient & SE & $\mathbf{P}$ & $\begin{array}{c}\text { Adjusted } \\
\text { R2 (\%) }\end{array}$ \\
\hline Sample size & -0.026 & 0.008 & 0.004 & 11.39 & 0 & 0 & 0.001 & \\
\hline Region & Reference & & & 7.46 & & & & \\
\hline EM-African & 0.049 & 0.032 & 0.127 & & 0.038 & 0.033 & 0.263 & \\
\hline European & 0.033 & 0.027 & 0.227 & & 0.045 & 0.031 & 0.146 & \\
\hline Americas & -0.010 & 0.030 & 0.732 & & -0.011 & 0.032 & 0.741 & \\
\hline SEA-WP & 0.002 & 0.002 & 0.204 & 0.66 & -0.001 & 0.004 & 0.749 & \\
\hline \multicolumn{9}{|l|}{ Study quality score } \\
\hline \multicolumn{9}{|l|}{ Level of gathering data } \\
\hline Subdistrict & Reference & & & 13.25 & & & & \\
\hline District & 0.081 & 0.061 & 0.190 & & 0.001 & 0.040 & 0.978 & \\
\hline Provincial & 0.053 & 0.064 & 0.408 & & -0.042 & 0.042 & 0.321 & \\
\hline$\geq 2$ provinces & 0.066 & 0.065 & 0.319 & & 0.027 & 0.043 & 0.530 & 29.82 \\
\hline$\geq 2$ subnational regions & 0.066 & 0.069 & 0.344 & & 0.015 & 0.040 & 0.709 & \\
\hline National & 0.055 & 0.062 & 0.3705 & & 0.070 & 0.041 & 0.092 & \\
\hline International & 0.129 & 0.062 & 0.041 & & - & - & - & \\
\hline Publication year & -0.001 & 0.002 & 0.577 & -1.14 & 0.001 & 0.002 & 0.572 & \\
\hline \multicolumn{9}{|l|}{ Sampling method } \\
\hline Census & Reference & & & -3.65 & & & & \\
\hline Random stratified sampling & 0.073 & 0.068 & 0.287 & & 0.043 & 0.071 & 0.552 & \\
\hline Random simple sampling & 0.089 & 0.066 & 0.183 & & 0.034 & 0.068 & 0.616 & \\
\hline One level clustering random & 0.064 & 0.073 & 0.384 & & 0.055 & 0.070 & 0.434 & \\
\hline Multilevel clustering random & 0.077 & 0.070 & 0.277 & & 0.065 & 0.072 & 0.372 & \\
\hline Others & 0.063 & 0.073 & 0.392 & & 0.017 & 0.077 & 0.824 & \\
\hline
\end{tabular}

*Significant at the $5 \%$ level. EM = Eastern Mediterranean; SE = standard error; $S E A=$ South-East Asia; WP = Western Pacific.

ethnicity than among other ethnicities (70). Eisner et al. concluded that communities with low socioeconomic status were at higher risk of COPD. They also observed a higher prevalence of COPD among populations with low education or income (71). A cohort study that followed a population of $>57000$ subjects for 35 years concluded that long-term exposure to traffic air pollutants may have contributed to the increase in COPD (72). In fact, some researchers believe that COPD would not really exist in the absence of smoking (73).

Our study was a systematic approach for the estimation of COPD severity stages worldwide. We found that most subjects with COPD were in stage 2 (moderate) by GOLD definitions. These findings are important for adjusting the estimation of the global burden of COPD, since the years lived with a disability (YLDs) for COPD is calculated based on the years lost due to disability weight, which is substantially different among different COPD stages. For example, the weight of disability for COPD in the GBD study in 2013 was 0.019 for stage 1 but 0.408 for stage 4 (74).

Our meta-analysis found a high level of heterogeneity among the studies included. Subgroup analysis by sex and region could not relieve this heterogeneity. Besides, we found that WHO region, level of collection data, and sample size were more associated with heterogeneity. However, after adjusting for all factors, we could only account for about $30 \%$ of the heterogeneity. This finding is similar to many other meta-analyses of prevalence studies $(60,75)$. This high heterogeneity of the prevalence may have been due to the variability of the prevalence in different populations and regions. It might also have been due to differences among studies regarding the years when they were conducted, their approach to population sampling, and data collection methods. In meta-analysis of prevalence, heterogeneity is more than expected for meta-analysis of relative risks. This could be due to significant real difference in the prevalence rates in various countries and regions (76).

The main limitations of our study were the lack of data for some key regions and inconsistency between the numbers of studies conducted in different regions, which led us to merge the data of $2 \mathrm{WHO}$ regions. The fact that we only included English-language papers was another limitation, since many papers discussed the subject in other languages. Moreover, the age group distribution was inconsistent between some papers so that we could 
not extract data for all age groups; consequently, we could not standardize the results for age and sex.

However, a strength of our study was the use of a standard definition of COPD to estimate the pooled global prevalence of COPD. This approach eliminated the role of the variable definitions of COPD in the heterogeneity of results in different studies. Another strength of our study was reporting the severity of COPD stages.

\section{Conclusion}

It seems that the prevalence of COPD is higher in the Region of the Americas than in other regions. Because of the lack of data in some regions such as the Eastern Mediterranean Region and African Region, we recommend conducting research on the prevalence, incidence, and mortality rate of COPD in these regions.

\section{Acknowledgements}

We would like to thank Dr. Michael Hanna for proofreading the manuscript and providing suggestions for improvements.

Funding: None.

Competing interests: None declared.

\section{Prévalence mondiale de la bronchopneumopathie chronique obstructive : analyse systématique et méta-analyse}

\section{Résumé}

Contexte : La bronchopneumopathie chronique obstructive (BPCO) est l'une des principales causes de morbidité et de mortalité dans le monde.

Objectifs :Réaliser une synthèse des données relatives à la prévalence et à la gravité de la BPCO par régions géographiques, tranches d'âges et statut tabagique à partir d'une analyse systématique de la littérature médicale disponible.

Méthodes: Une recherche systématique a été réalisée conformément aux lignes directrices pour la méta-analyse des études observationnelles (MOOSE). Des recherches ont été lancées dans des bases de données internationales, notamment PubMed, Scopus et Web of Science, afin d'identifier les études populationnelles, publiées entre janvier 2004 et mai 2015, faisant état de la prévalence de la BPCO partout dans le monde. La prévalence de la BPCO a été calculée à l'aide du programme Metaprop en fonction des régions définies par l'Organisation mondiale de la Santé (OMS), du sexe et du stade de sévérité. Des méthodes de méta-régression et d'analyse de sous-groupes ont été appliquées afin d’identifier les sources d'hétérogénéité.

Résultats : Au total, 60 articles ont été analysés portant sur un échantillon composite de 127598 sujets. La prévalence de la BPCO après utilisation d'un bronchodilatateur était de $12,16 \%(10,91$ à 13,40 \%). La prévalence globale de la BPCO était de $15,70 \%$ (13,80 à 18,59\%) chez les hommes et de 9,93\% (8,73 à 11,13\%) chez les femmes. Sur l'ensemble des régions OMS, la prévalence la plus forte était enregistrée pour les Amériques (14,53 \%) et la plus faible pour l'Asie du Sud-Est/le Pacifique occidental $(8,80 \%)$. Les variables du modèle de méta-régression utilisé incluaient la taille de l'échantillon, la région, le score de la qualité de l'étude, le niveau des données recueillies, l'année de publication et la méthode d'échantillonnage, justifiant ainsi l'hétérogénéité de $29,82 \%$ associée aux taux de prévalence de la BPCO à travers le monde.

Conclusions : La prévalence mondiale de la BPCO chez les hommes s'avère supérieure d'environ $5 \%$ à celle observée chez les femmes. Le stade 1 de la BPCO est celui ayant la prévalence la plus élevé.

$$
\begin{aligned}
& \text { معدل الانتشار العالمي لمرض الانسداد الرئوي المزمن: استعر اض منهجي وتحليل تلوي } \\
& \text { مهدي ورمقاني، مينا دهقاني، إلهام حيدري، فرشاد شريفي، سحر سعيدي مقدم، فرشاد فرزادفر } \\
& \text { الخالاصة } \\
& \text { الخلفية: يُعَلُّ مرض الانسداد الرئوي المزمن أحد الأسباب الرئيسية التي تسبب المراضة والوفيات على مستوى العالم. }
\end{aligned}
$$

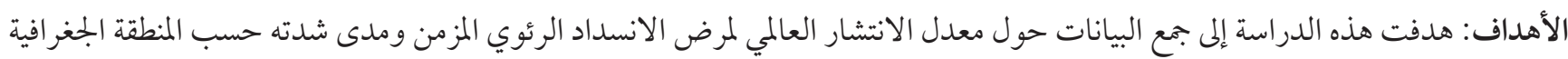

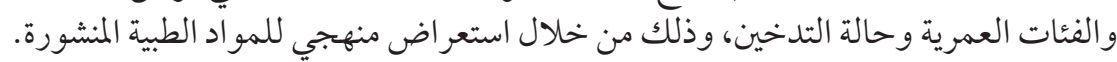

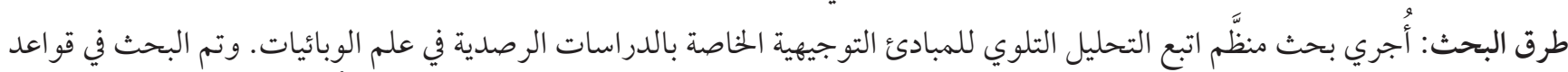

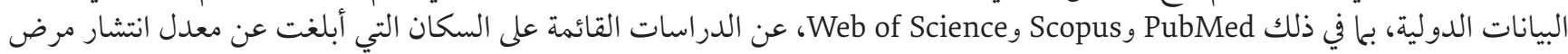

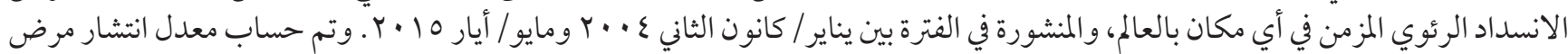




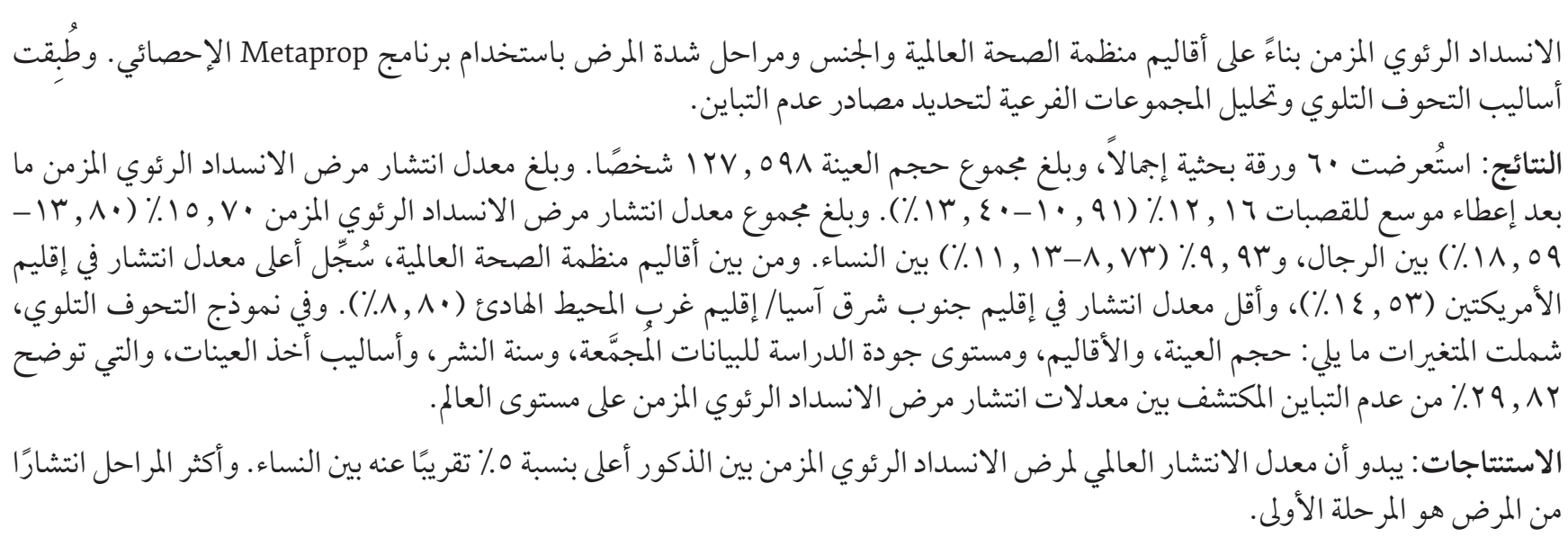

\section{References}

1. Lozano R, Naghavi M, Foreman K, Lim S, Shibuya K, Aboyans V, et al. Global and regional mortality from 235 causes of death for 20 age groups in 1990 and 2010: a systematic analysis for the Global Burden of Disease Study 2010. Lancet. 2012 Dec15;380(9859):2095-128. http://dx.doi.org/10.1016/S0140-6736(12)61728-o PMID:23245604

2. Mason RJ, Broaddus VC, Martin TR, King Jr TE, Schraufnagel D, Murray JF, et al., editors. Murray and Nadel's textbook of respiratory medicine: 2-volume set, 5th edition. Philadelphia: Saunders Elsevier; 2010.

3. Guarascio AJ, Ray SM, Finch CK, Self TH. The clinical and economic burden of chronic obstructive pulmonary disease in the USA. Clinicoecon Outcomes Res. 2013 Jun 17;5:235-45. http://dx.doi.org/10.2147/CEOR.S34321 PMID:23818799

4. Turco P. Costs of illness analysis in Italian patients with chronic obstructive pulmonary disease (COPD): an update. Clinicoecon Outcomes Res. 2015 Mar 16;7:153-9. http://dx.doi.org/10.2147/CEOR.S77504 PMID:25834458

5. Adeloye D, Chua S, Lee C, Basquill C, Papana A, Theodoratou E, et al. Global and regional estimates of COPD prevalence: systematic review and meta-analysis. J Glob Health. 2015 Dec;5(2):020415. http://dx.doi.org/10.7189/jogh.05.020415 PMID:26755942

6. 6. Johannessen A, Omenaas ER, Bakke PS, Gulsvik A. Implications of reversibility testing on prevalence and risk factors for chronic obstructive pulmonary disease: a community study. Thorax. 2005 Oct;60(10):842-7. http://dx.doi.org/10.1136/ thx.2005.043943 PMID:16085729

7. Stroup DF. Meta-analysis of observational studies in epidemiology: a proposal for reporting. JAMA. 2000 Apr 19;283(15):2008-12. http://dx.doi.org/10.1001/jama.283.15.2008 PMID:10789670

8. Vestbo J, Hurd SS, Agustí AG, Jones PW, Vogelmeier C, Anzueto A, et al. Global strategy for the diagnosis, management, and prevention of chronic obstructive pulmonary disease: GOLD executive summary. Am J Respir Crit Care Med. 2013 Feb 15;187(4):34765. http://dx.doi.org/10.1164/rccm.201204-0596PP PMID:22878278

9. Hansen JG, Pedersen L, Overvad K, Omland Ø, Jensen HK, Sørensen HT. The prevalence of chronic obstructive pulmonary disease among Danes aged 45-84 years: population-based study. COPD. 2008 Dec;5(6):347-52. http://dx.doi. org/10.1080/15412550802522635 PMID:19353348

10. Buist AS, McBurnie MA, Vollmer WM, Gillespie S, Burney P, Mannino DM, et al. International variation in the prevalence of COPD (the BOLD Study): a population-based prevalence study. Lancet. 2007 Sep 1;370(9589):741-50. http://dx.doi.org/10.1016/ So140-6736(07)61377-4 PMID:17765523

11. Al Zaabi A, Asad F, Abdou J, Al Musaabi H, Al Saiari MB, Mohammed Buhussien AS, et al. Prevalence of COPD in Abu Dhabi, United Arab Emirates. Respir Med. 2011 Apr;105(4):566-70. http://dx.doi.org/10.1016/j.rmed.2010.12.008 PMID:21216136

12. Al-Hazmi M, Wooldrage K, Anthonisen NR, Becklake MR, Bowie D, Chan-Yeung M, et al. Airflow obstruction in young adults in Canada. Can Respir J. 2007 May-Jun;14(4):221-7. http://dx.doi.org/10.1155/2007/987249 PMID:17551598

13. Arslan Z, Ilgazlı A, Etiler N, Hamzaoğlu O. Prevalence of chronic obstructive pulmonary disease in Kocaeli: an industrialised city in Turkey. Balkan Med J. 2013 Dec;30(4):387-93. http://dx.doi.org/10.5152/balkanmedj.2013.8042 PMID:25207146

14. Bridevaux P-O, Probst-Hensch NM, Schindler C, Curjuric I, Felber Dietrich D, Braendli O, et al. Prevalence of airflow obstruction in smokers and never-smokers in Switzerland. Eur Respir J. 2010 Dec;36(6):1259-69. http://dx.doi.org/10.1183/09031936.00004110 PMID:20413537

15. Caballero A, Torres-Duque CA, Jaramillo C, Bolívar F, Sanabria F, Osorio P, et al. Prevalence of COPD in five Colombian cities situated at low, medium, and high altitude (PREPOCOL study). Chest. 2008 Feb;133(2):343-9. http://dx.doi.org/10.1378/chest.07-1361 PMID:17951621

16. Daldoul H, Denguezli M, Jithoo A, Gnatiuc L, Buist S, Burney P, et al. Prevalence of COPD and tobacco smoking in Tunisia results from the BOLD Study. Int J Environ Res Public Health. 2013 Dec;10(12):7257-71. http://dx.doi.org/10.3390/ijerph10127257 PMID:24351745

17. Danielsson P, Ólafsdóttir IS, Benediktsdóttir B, Gíslason T, Janson C. The prevalence of chronic obstructive pulmonary disease in Uppsala, Sweden - the Burden of Obstructive Lung Disease (BOLD) study: cross-sectional population-based study. Clin Respir J. 


\section{Apr;6(2):120-7. http://dx.doi.org/10.1111/j.1752-699X.2011.00257.x PMID:21651748}

18. de Marco R, Accordini S, Cerveri I, Corsico A, Sunyer J, Neukirch F, et al. An international survey of chronic obstructive pulmonary disease in young adults according to GOLD stages. Thorax. 2004 Feb;59(2):120-5. http://dx.doi.org/10.1136/thorax.2003.011163 PMID:14760151

19. Fabricius P, Løkke A, Marott JL, Vestbo J, Lange P. Prevalence of COPD in Copenhagen. Respir Med. 2011 Mar;105(3):410-7. http:// dx.doi.org/10.1016/j.rmed.2010.09.019 PMID:20952174

20. Ford ES, Mannino DM, Wheaton AG, Giles WH, Presley-Cantrell L, Croft JB. Trends in the prevalence of obstructive and restrictive lung function among adults in the United States: findings from the National Health and Nutrition Examination surveys from 1988-1994 to 2007-2010. Chest. 2013 May;143(5):1395-406. http://dx.doi.org/10.1378/chest.12-1135 PMID:23715520

21. Frank TL, Hazell ML, Linehan MF, Morris JA, Frank PI. The estimated prevalence of chronic obstructive pulmonary disease in a general practice population. Prim Care Respir J. 2007 Jun;16(3):169-73. http://dx.doi.org/10.3132/pcrj.2007.00028 PMID:17530148

22. Fukuchi Y, Nishimura M, Ichinose M, Adachi M, Nagai A, Kuriyama T, et al. COPD in Japan: the Nippon COPD Epidemiology study. Respirology. 2004 Nov;9(4):458-65. http://dx.doi.org/10.1111/j.1440-1843.2004.00637.x PMID:15612956

23. Hwang YI, Yoo KH, Sheen SS, Park JH, Kim S-H, Yoon HI, et al. Prevalence of chronic obstructive pulmonary disease in Korea: the result of Forth Korean National Health and Nutrition Examination Survey. Tuberc Respir Dis. 2011;71(5):328-34. http://dx.doi. org/10.4046/trd.2011.71.5.328

24. Joo H, Park J, Lee SD, Oh Y-M. Comorbidities of chronic obstructive pulmonary disease in Koreans: a population-based study. J Korean Med Sci. 2012 Aug;27(8):901-6. http://dx.doi.org/10.3346/jkms.2012.27.8.901 PMID:22876057

25. Kainu A, Rouhos A, Sovijärvi A, Lindqvist A, Sarna S, Lundbäck B. COPD in Helsinki, Finland: socioeconomic status based on occupation has an important impact on prevalence. Scand J Public Health. 2013;41(6):570-8. http://dx.doi. org/10.1177/1403494813484554

26. Kim DS, Kim YS, Jung K-S, Chang JH, Lim C-M, Lee JH, et al. Prevalence of chronic obstructive pulmonary disease in Korea: a population-based spirometry survey. Am J Respir Crit Care Med. 2005 Oct 1;172(7):842-7. http://dx.doi.org/10.1164/rccm.200502-259OC PMID:15976382

27. Kim S, Suk M, Choi H, Kimm K, Jung K, Lee S, et al. The local prevalence of COPD by post-bronchodilator GOLD criteria in Korea. Int J Tuberc Lung Dis. 2006 Dec;10(12):1393-8. PMID:17167958

28. Jyrki-Tapani K, Sovijärvi A, Lundbäck B. Chronic obstructive pulmonary disease in Finland: prevalence and risk factors. COPD 2005 Sep;2(3):331-9. PMID:17146998.

29. Lindberg A, Bjerg-Bäcklund A, Rönmark E, Larsson L-G, Lundbäck B. Prevalence and underdiagnosis of COPD by disease severity and the attributable fraction of smoking: report from the Obstructive Lung Disease in Northern Sweden Studies. Respir Med. 2006 Feb;100(2):264-72. http://dx.doi.org/10.1016/j.rmed.2005.04.029 PMID:15975774

30. Mahesh P, Jayaraj B, Prahlad S, Chaya S, Prabhakar A, Agarwal A, et al. Validation of a structured questionnaire for COPD and prevalence of COPD in rural area of Mysore: a pilot study. Lung India. 2009 Jul;26(3):63. http://dx.doi.org/10.4103/0970-2113.53226 PMID:20442838

31. Mascarenhas J, Falcão H, Lourenço P, Paulo C, Patacho M, Bettencourt P, et al. Population-based study on the prevalence of spirometric obstructive pattern in Porto, Portugal. Respir Care. 2011 May;56(5):619-25. http://dx.doi.org/10.4187/respcare.00698 PMID:21276282

32. Matsumoto K, Seki N, Fukuyama S, Moriwaki A, Kan-o K, Matsunaga Y, et al. Prevalence of asthma with airflow limitation, COPD, and COPD with variable airflow limitation in older subjects in a general Japanese population: The Hisayama Study. Respir Investig. 2015 Jan;53(1):22-9. http://dx.doi.org/10.1016/j.resinv.2014.08.002 PMID:25542600

33. Melville A, Pless-Mulloli T, Afolabi O, Stenton S. COPD prevalence and its association with occupational exposures in a general population. Eur Respir J. 2010 Sep;36(3):488-93. http://dx.doi.org/10.1183/09031936.00038309 PMID:20110401

34. Methvin JN, Mannino DM, Casey BR. COPD prevalence in southeastern Kentucky: the burden of lung disease study. Chest. 2009 Jan;135(1):102-7. http://dx.doi.org/10.1378/chest.08-1315 PMID:18689574

35. Minas M, Hatzoglou C, Karetsi E, Papaioannou AI, Tanou K, Tsaroucha KT, et al. COPD prevalence and the differences between newly and previously diagnosed COPD patients in a spirometry program. Prim Care Respir J. 2010 Dec;19(4):363-70. http://dx.doi. org/10.4104/pcrj.2010.00034 PMID:20532466

36. Miravitlles M, Soriano JB, Garcia-Rio F, Muñoz L, Duran-Tauleria E, Sanchez G, et al. Prevalence of COPD in Spain: impact of undiagnosed COPD on quality of life and daily life activities. Thorax. 2009 Oct;64(10):863-8. http://dx.doi.org/10.1136/thx.2009.115725 PMID:19553233

37. Nizankowska-Mogilnicka E, Mejza F, Buist AS, Vollmer WM, Skucha W, Harat R, et al. Prevalence of COPD and tobacco smoking in Malopolska region-results from the BOLD study in Poland. Pol Arch Med Wewn. 2007 Sep;117(9):402. PMID:18062562

38. Parasuramalu BG, Huliraj N, Kumar SP, Masthi NR, Babu CS. Prevalence of chronic obstructive pulmonary disease and its association with tobacco smoking and environmental tobacco smoke exposure among rural population. Indian J Public Health. 2014 Jan-Mar;58(1):45. http://dx.doi.org/10.4103/0019-557X.128166 PMID:24748357

39. Schirnhofer L, Lamprecht B, Vollmer WM, Allison MJ, Studnicka M, Jensen RL, et al. COPD prevalence in Salzburg, Austria: results from the Burden of Obstructive Lung Disease (BOLD) study. Chest Journal. 2007 Jan;131(1):29-36. http://dx.doi.org/10.1378/ chest.06-0365 PMID:17218553 
40. Shahab L, Jarvis M, Britton J, West R. Prevalence, diagnosis and relation to tobacco dependence of chronic obstructive pulmonary disease in a nationally representative population sample. Thorax. 2006 Dec;61(12):1043-7. http://dx.doi.org/10.1136/ thx.2006.064410 PMID:17040932

41. Sichletidis L, Tsiotsios I, Gavriilidis A, Chloros D, Kottakis I, Daskalopoulou E, et al. Prevalence of chronic obstructive pulmonary disease and rhinitis in northern Greece. Respiration. 2005 May-Jun;72(3):270-7. http://dx.doi.org/10.1159/000085368 PMID:15942296

42. Shirtcliffe P, Weatherall M, Marsh S, Travers J, Hansell A, McNaughton A, et al. COPD prevalence in a random population survey: a matter of definition. Eur Respir J. 2007 Aug;30(2):232-9. http://dx.doi.org/10.1183/09031936.00157906 PMID:17666557

43. Szanto O, Montnemery P, Elmstahl S. Prevalence of airway obstruction in the elderly: results from a cross-sectional spirometric study of nine age cohorts between the ages of 60 and 93 years. Prim Care Respir J. 2010 Sep;19(3):231-6. http://dx.doi.org/10.4104/ pcrj.2010.00011 PMID:20228994

44. Tan WC, Bourbeau J, FitzGerald J, Cowie R, Chapman K, Hernandez P, et al. Can age and sex explain the variation in COPD rates across large urban cities? A population study in Canada. Int J Tuberc Lung Dis. 2011 Dec;15(12):1691-8. http://dx.doi.org/10.5588/ ijtld.11.0211 PMID:22118181

45. Lâm HT, Ekerljung L. Tuòng NV, Rönmark E, Larsson K, Lundbäck B. Prevalence of COPD by disease severity in men and women in northern Vietnam. COPD. 2014 Sep;11(5):575-81. http://dx.doi.org/10.3109/15412555.2014.898039 PMID:24867392

46. Toelle BG, Xuan W, Bird TE, Abramson MJ, Atkinson DN, Burton DL, et al. Respiratory symptoms and illness in older Australians: the Burden of Obstructive Lung Disease (BOLD) study. Med J Aust. 2013;198(3):144-8. http://dx.doi.org/10.5694/mja11.11640

47. van Gemert F, Kirenga B, Chavannes N, Kamya M, Luzige S, Musinguzi P, et al. Prevalence of chronic obstructive pulmonary disease and associated risk factors in Uganda (FRESH AIR Uganda): a prospective cross-sectional observational study. Lancet Glob Health. 2015 Jan;3(1):e44-51. http://dx.doi.org/10.1016/S2214-109X(14)70337-7 PMID:25539969

48. Vanfleteren LE, Franssen FM, Wesseling G, Wouters EF. The prevalence of chronic obstructive pulmonary disease in Maastricht, the Netherlands. Respir Med. 2012 Jun;106(6):871-4. http://dx.doi.org/10.1016/j.rmed.2012.01.008 PMID:22349067

49. Wali SO, Idrees MM, Alamoudi OS, Abulfarag AM, Salem AD, Aljohaney AA, et al. Prevalence of chronic obstructive pulmonary disease in Saudi Arabia. Saudi Med J. 2014 Jul;35(7):684-90. PMID:25028224

50. Wilson D, Adams R, Appleton S, Ruffin R. Difficulties identifying and targeting COPD and population-attributable risk of smoking for COPD: a population study. Chest. 2005 Oct;128(4):2035-42. http://dx.doi.org/10.1378/chest.128.4.2035 PMID:16236852

51. Zhong N, Wang C, Yao W, Chen P, Kang J, Huang S, et al. Prevalence of chronic obstructive pulmonary disease in China: a large, population-based survey. Am J Respir Crit Care Med. 2007 Oct 15;176(8):753-60. http://dx.doi.org/10.1164/rccm.200612-1749OC PMID:17575095

52. Petrescu C, Suciu O, Herbarth O, Ionovici R, Franck U, Schlink U. Respiratory health effects of air pollution and climate parameters in the population of Drobeta Turnu-Severin. Romania: INTECH Open Access Publisher; 2011. http://dx.doi.org/10.5772/21015

53. Sharifi H, Masjedi MR, Emami H, Ghanei M, Eslaminejad A, Radmand G, et al. Burden of obstructive lung disease study in Tehran: Prevalence and risk factors of chronic obstructive pulmonary disease. Lung India. 2015 Nov-Dec;32(6):572. http://dx.doi. org/10.4103/0970-2113.168129 PMID:26664162

54. Menezes AMB, Perez-Padilla R, Jardim JB, Muiño A, Lopez MV, Valdivia G, et al. Chronic obstructive pulmonary disease in five Latin American cities (the PLATINO study): a prevalence study. Lancet. 2005;366(9500):1875-81. http://dx.doi.org/10.1016/So1406736(05)67632-5 PMID:26664162

55. Lindberg A, Jonsson A-C, Rönmark E, Lundgren R, Larsson L-G, Lundbäck B. Prevalence of chronic obstructive pulmonary disease according to BTS, ERS, GOLD and ATS criteria in relation to doctor's diagnosis, symptoms, age, gender, and smoking habits. Respiration. 2005 Sep-Oct;72(5):471-9. http://dx.doi.org/10.1159/000087670 PMID:16210885

56. Chuchalin AG, Khaltaev N, Antonov NS, Galkin DV, Manakov LG, Antonini P, et al. Chronic respiratory diseases and risk factors in 12 regions of the Russian Federation. Int J Chron Obstruct Pulmon Dis. 2014 Sep 12;9:963-74. http://dx.doi.org/10.2147/COPD. S67283 PMID:25246783

57. Jarad N. Chronic obstructive pulmonary disease (COPD) and old age? Chron Respir Dis. 2011;8(2):143-51. http://dx.doi. org/10.1177/1479972311407218 PMID:21596895

58. Tayde P, Kumar S. Chronic obstructive pulmonary disease in the elderly: evaluation and management. Asian J Gerontol Geriatr. 2013 Dec;8(2):90-7.

59. Khan S, Fell P, James P. Smoking-related chronic obstructive pulmonary disease (COPD). Diversity Equality Health Care. 2014;11(3/4):267-71.

6o. Halbert R, Natoli J, Gano A, Badamgarav E, Buist AS, Mannino DM. Global burden of COPD: systematic review and meta-analysis. Eur Respir J. 2006 Sep;28(3):523-32. http://dx.doi.org/10.1183/09031936.06.00124605 PMID:16611654

61. Ciapponi A, Alison L, Agustina M, Demián G, Silvana C, Edgardo S. The epidemiology and burden of COPD in Latin America and the Caribbean: systematic review and meta-analysis. COPD. 2014 Jun;11(3):339-50. http://dx.doi.org/10.3109/15412555.2013.836479 PMID:24111903

62. Adeloye D, Basquill C, Papana A, Chan KY, Rudan I, Campbell H. An estimate of the prevalence of COPD in Africa: a systematic analysis. COPD. 2015 Feb;12(1):71-81. http://dx.doi.org/10.3109/15412555.2014.908834 PMID:24946179 
63. Loganathan RS, Stover DE, Shi W, Venkatraman E. Prevalence of COPD in women compared to men around the time of diagnosis of primary lung cancer. Chest. 2006 May;129(5):1305-12. http://dx.doi.org/10.1378/chest.129.5.1305 PMID:16685023

64. Afonso AS, Verhamme KM, Sturkenboom MC, Brusselle GG. COPD in the general population: prevalence, incidence and survival. Respir Med. 2011 Dec;105(12):1872-84. http://dx.doi.org/10.1016/j.rmed.2011.06.012

65. Artyukhov IP, Arshukova IL, Dobretsova EA, Dugina TA, Shulmin AV, Demko IV. Epidemiology of chronic obstructive pulmonary disease: a population-based study in Krasnoyarsk region, Russia. Int J Chron Obstruct Pulmon Dis. 2015 Sep 2;10:1781. PMID:26366070 http://dx.doi.org/10.2147/COPD.S79601 PMID:21852081

66. Ng M, Freeman MK, Fleming TD, Robinson M, Dwyer-Lindgren L, Thomson B, et al. Smoking prevalence and cigarette consumption in 187 countries, 1980-2012. JAMA. 2014 Jan 8;311(2):183-92. http://dx.doi.org/10.1001/jama.2013.284692 PMID:24399557

67. Kant S, Gupta B. Role of lifestyle in the development of chronic obstructive pulmonary disease: a review. Lung India. $2008 \mathrm{Apr}-$ Jun;25(2):95. http://dx.doi.org/10.4103/0970-2113.59591 PMID:20165658

68. Sandford A, Weir T, Pare PD. Genetic risk factors for chronic obstructive pulmonary disease. Eur Respir J. 1997 Jun;10(6):1380-91. http://dx.doi.org/10.1183/09031936.97.10061380 PMID:9192947

69. Wang F, Ni S-S, Liu H. Pollutional haze and COPD: etiology, epidemiology, pathogenesis, pathology, biological markers and therapy. J Thorac Dis. 2016 Jan;8(1):E20-30. http://dx.doi.org/10.3978/j.issn.2072-1439.2015.11.62 PMID:26904250

70. Martin A, Badrick E, Mathur R, Hull S. Effect of ethnicity on the prevalence, severity, and management of COPD in general practice. Br J Gen Pract. 2012 Feb;62(595):e76-81. http://dx.doi.org/10.3399/bjgp12X625120 PMID:22520773

71. Eisner MD, Blanc PD, Omachi TA, Yelin EH, Sidney S, Katz PP, et al. Socioeconomic status, race and COPD health outcomes. J Epidemiol Community Health. 2009 Jan;65(1):26-34. http://dx.doi.org/ 10.1136/jech.2009.089722 PMID: 19854747

72. Andersen ZJ, Hvidberg M, Jensen SS, Ketzel M, Loft S, Sørensen M, et al. Chronic obstructive pulmonary disease and longterm exposure to traffic-related air pollution: a cohort study. Am J Respir Crit Care Med. 2011 Feb 15;183(4):455-61. http://dx.doi. org/10.1164/rccm.201006-0937OC PMID:20870755

73. Fabbri LM. Smoking, not COPD, as the disease. N Engl J Med. 2016 May 12;374(19):1885-6. http://dx.doi.org/10.1056/NEJMe1515508 PMID:27168438

74. Salomon JA, Haagsma JA, Davis A, de Noordhout CM, Polinder S, Havelaar AH, et al. Disability weights for the Global Burden of Disease 2013 study. Lancet Glob Health. 2015 Nov;3(11):e712-23. http://dx.doi.org/10.1016/S2214-109X(15)00069-8 PMID:26475018

75. Varmaghani M, Farzadfar F, Sharifi F, Rashidain A, Moin M, Moradi-Lakeh M, et al. Prevalence of asthma, COPD, and chronic bronchitis in Iran: a systematic review and meta-analysis. Iran J Allergy Asthma Immunol. 2016 Apr;15(2):93-104. PMID:27090362

76. Higgins JP. Commentary: Heterogeneity in meta-analysis should be expected and appropriately quantified. Int J Epidemiol. 2008;37(5):1158-60. http://dx.doi.org/10.1093/ije/dyn204 